\title{
СВІТОГЛЯДНІ ТРАНСФОРМАЦІЇ УКРАЇНСЬКОЇ ФІЛОСОФСЬКОї ДУМКИ НОВОГО ЧАСУ
}

\section{В.Ф. Капіца, О.П. Звенігородська}

Формування національної світоглядно-філософської думки почало відбуватися в історичний період Нового часу. Воно було споріднено 3 «ренесансним духом» епохи Відродження української національної культури та мислення. Україна в цьому культурно-історичному процесі виступила як одна із східно-європейських націй. Тому можна вважати, що передумови для світоглядних трансформацій в українській філософській думці сформувалися за часів «ренесансного гуманізму» початку-середини XVI століття. Перші світоглядні трансформації на національному підгрунті відбулися в площині реформаторських ідей діячів українського «братського руху», що мав першоджерела в Києво-Печерській Лаврі. Серед перших великих українських гуманістівпросвітителів були такі мислителі як Касіян Сакович, Іван Вишенський, Кирило Транквіліон-Ставровецький, Симон Пекалід та інші [1]. Братські реформаційні вчення, які розроблялися філософами «братських шкіл» Острозького і Києво-Могилянського культурно-освітніх центрів, створили не тільки передумови національно-визвольного руху в Україні у першій половині XVIII ст., але й сформували просвітницько-реформаційний та ліберально-свободолюбиві світоглядні уявлення «від геоцентризму до пізнання природи і людини», бо «ренесансна філософія не акцентує увагу на абсолютній свободі Бога. ., , натомість підходить до ідеї співвічності Бога і світу та його злиття з законом природної необхідності» [9, с. 41-42].

Але зрілі філософсько-гуманістичні світоглядні уявлення розвинулися лише під проводом Києво-Могилянської академії. На наш погляд, могилянськими професорами була створена дійсно нова світоглядна

Актуальні проблеми духовності

(Відп. ред.: Я.В. Шрамко)

Кривий Ріг (2006), 240-247 
парадигма суспільного буття на основі демократичної культури. Така світоглядна парадигма в європейських суспільствах тільки виплековувалась, а в Україні вже були створені певні світоглядно-конституційні засади нової демократичної державності. Демократично-конституційний «Вивід прав народу України» та інших європейських народів вперше створив Пилип Орлик. Але в системно-світоглядному відношенні цей «Вивід...» був обгрунтований в поглядах таких видатних українських філософів-гуманістів як Петро Могила, Єпіфаній Славинецький, Інокентій Гізель, Данило Туптало, Феофан Прокопович, Георгій Кониський та інші. На системній основі в Києво-Могилянській Академії викладаються світоглядно-філософські курси про людину, природу і світ, антична філософія Платона і Аристотеля, курси етики і естетики, природознавства Нового часу, філософська антропологія, фізика і метафізика, субстанційних початків буття, гносеології і людського мислення [9, с. 111-186, 327-405]. Україна - «територія між Сходом і Заходом» - стверджується як «територія уявлень і стереотипів» єдиної нації з визначеним національним світоглядом, відмінним від російського, польського, литовського та інших [16, с. 13-33, 333-335]. Створюється своє національне «коріння ідентичності» в національному світогляді, який починає формуватися самостійно і на своїй власній основі в історичний період, що фіксується як «ранньомодерна та модерна історія України» (XVI-XVIII ст.). Хоча «елементи» національної свідомості розвиваються переважно у вигляді «малоросійської самосвідомості» в контексті перших намагань «українського національного будівництва». Проте цей процес має чіткий «європейський напрямок» як модель «західної національної держави». Подібний тип державності передбачає, що «територія, політична структура, етнічність, мова й культура мають бути більшою чи меншою мірою одним цілим» [6, с.80-82]. Тобто мати вираження в єдиному суспільному світогляді національної ідентичності. Національна свідомість формується під впливом таких чинників, як незалежність мовної спільноти, історичної традиції (у тому числі правові традиції або звичаї), релігія, потреба у створенні народного героя (моральні ідеї) і територіальна спільнота, прагнення незалежної державності $[17$, с. 378]. Всі ці чинники не $є$ абсолютно необхідними, проте наявність тільки одного чи двох з них недостатньо для їх спільної дії, більш того, вони з часом можуть змінюватися, трансформуватися.

Філософське вчення Г. Сковороди підводить своєрідний підсумок української філософської думки XVII-XVIII ст. За В. Зеньковським, Г. Сковорода $\epsilon$ «перший філософ на Русі в точному розумінні цього 
слова». Він розвиває унікальну філософію «духовного серця», переводячи трансцендентальну «метафізику людини» у «духовну діалектику» людини $[11$, с.64]. Г. Сковорода базує свою висхідну світоглядну концепцію на тому, що пізнання йде від «живого духу» людини, i. безпосередньо-почуттєвої духовності, і тому це є почуттєво-духовним пізнанням. В ньому зливаються онтологія і гносеологія, етика «людської філософії» в антропофілософії і антропопізнанні. «Істинна людина» $є$ та, що несе в своєму серці «духовний логос». I тому вона має «духовне серце», що $є$ «душею» людини. 3 цим людина набуває здатності до «душевності», яка органічно притаманна українцям: «серце $\epsilon$ корінь і сутність», а що є серце, коли не душа...». Духовне серце це «безодня, котра все обіймає», живильне джерело розвитку людини і iї думок. Сама ж «думка є таємна пружина всієї нашої тілесної машини». Людина - це «тілесна машина» 3 «духовним серцем» або душею $[11$, c. 182].

Філософські ідеї Г. Сковороди справили великий вплив на подальший розвиток соціально-філософського підгрунтя українського національного світогляду. 3 середини XIX ст. «просвітницький романтизм» історичного розвитку національного світогляду поступово трансформується у практично-позитивну феноменологію національного духу, що знаменує новий період національного самоусвідомлення. В 60-70-х роках XIX ст. починають з'являтися цілі філософські системи, в яких на вітчизняному підгрунті розробляються класичні ідеї західної філософії. На базі Київської духовної академії формується Київська школа філософської думки: П.Д. Юркевич, Ф.А. Голубинський, В.Н. Карпов, С.С. Гогоцький та інші. Корінний зв'язок з філософськими ідеями Г.С. Сковороди очевидний за їх пристрастями - це філософія людського духу і людської душі («серця»), кардіофілософія. Системність філософських поглядів українських філософів набуває цілком виразного характеру західної філософії: це позитивний «реалізм» Г. Челпанова, емпіризм В.Лесевича, персоналізм А.Гілярова, філософія «духовної сили» М. Грота, «духовної свідомості» М. Бердяєва, С. Булгакова і Л. Шестова, філософія історії національного духу В. Зеньковського, філософія семантики національного духу (мови і міфу) О. Потебні, філософія релятивізму П. Кудрявцева, «ноосферна філософія» В. Вернадського [10, с. 265-279].

Класичний академізм європейського рівня був притаманним філософській творчості Памфіла Юркевича (друга половина XIX ст.). Одночасно він розвивав кращі традиції національної філософської думки. Його фундаментальну філософську працю «Серце і його значен- 
ня в духовному житті людини» можна вважати здійсненим відродженням «філософії серця» протоукраїнства на сучасній науковій основі філософської антропології [14, с. 69-130]. 3 ншого боку П. Юркевич спирається на античну та сучасну філософію в своїх працях «Ідея», «Розум за вченням Платона і досвід за вченням Канта», проводячи свій «духовний аналіз» $з$ позицій формування національного світогляду українського суспільства. Духовно-кардіософічна антропологія П. Юркевича цілеспрямовано виходить на людську душу як осереддя духовного життя людини і створює цілу «науку про людський дух» $[15$, с. 104-192]. Цей дух - вмістилище справжнього внутрішнього досвіду людини, тому що встановлює «задушевність», тобто психічну глибину людини. Тільки за наявності цієї психічної глибини може виникнути мислення у людини, і вся робота розуму формується на постійному «підживленні» 3 цього духовного джерела [14, с. 71-73].

Світоглядну теорію ідей у вигляді «духовних ідей» $\mathrm{i}$ «деології духу», за П. Юркевичем, можна представити у такому світоглядному узагальненні трьох родів ідей духу. До першого роду належать «вічні ідеї» - це причини причин, «вічні істини», що як «онтологічні ейдоси реально існують в земно-буттєвому стані «надсутносністі» духу (це реальна «надсутність» на відміну від платонівського ідеального «світу ейдосів»). До другого роду належать «людські ідеї», які $\epsilon$ «кінечними ідеями» і відносними істинами у статусі «мислимих ідей»: вони вже $\epsilon$ «гносеологічними ейдосами» духовного блага як добродіючи «істини блага». Ідея третього роду синтетична. Це світоглядна ідея духовно-почуттєвої реалізації людини шляхом безпосередньої духовної практики і опанування відповідними духовно-практичними методами самореалізації.

Г. Челпанов надає національному світогляду характер «гносеологічного реалізму». Такий світогляд був обумовлений тим, що Г. Челпанов сам був не тільки професійним філософом, але й ведучим провідником школи наукової психології («експериментальної»). Такі його відомі праці, як «Проблемы восприятия пространства», «Введение в философию» підкріплювалися не менш значними психологічними розробками, такими як «Мозг и душа», «Очерки психологии» та інші. Саме досягнення психології цього часу приводили багатьох вчених і філософів-позитивістів до заперечення метафізики як «ненаукової» філософії. У Г. Челпанова цього не трапилось, і тут, на нашу думку, важливу роль відіграли особливості його національного світогляду [12, c. $126,415-418]$.

Надзвичайно цікавими $є$ філософські розробки В.В.Лесевича, го- 
ловні 3 яких «Опыт критического исследования основоначал позитивной философии», «Письма о научной философии» та інші. В висхідних концепціях В.Лесевич начебто йде за західним новітнім емпіріокритицизмом. Але філософський метод, який він застосовує, інший - це метод критичного реалізму. I хоча його головна спрямованість антиметафізична, і з мислення вимагається виключити всі «апріорні заблудження» розуму, вилучити все «трансцендентальне і безумовне», його кінцева мета - це побудова світоглядних уявлень у формі «наукового світогляду». Система позитивного наукового світогляду у В. Лесевича виглядає так: 1) впровадження позитивного методу функціональної залежності як «співвідносності причини і дії» замість містико-метафізичної причинності; 2) теза про відносність знання, першості науки перед філософією за своїм фактичним змістом подається в контексті представлення філософії в пріоритетному значенні «наукової філософіï», «позитивної філософії [8, с. 6]; 3) відносність знання розуміється в тому, що важливі не факти самі по собі («фактопоклонство»), а правильне утворення наукових понять; 4) наукові поняття формуються в процесі застосування суб'єктивного методу, тобто коли привноситься в оцінку дослідника у судженні про дійсність, а самі ж оцінки основані на науковому спостереженні і не мають морального аспекту; 5) знання є підстава для дії, і в такому аспекті повинна виступати і філософія: вона повинна стати основою людської діяльності в аспекті суті, спонукання і мети.

Особливу увагу в своїй гносеології В. Лесевич відводить філософії, iii перетворенню на основі позитивізму в «наукову філософію», суттю якої $€$ «науково-філософський світогляд» [8, с. 191]. Суб'єктивний метод науково-філософського дослідження повинен бути пов'язаним 3 методом, який об'єктивує: «Научная философия обнимает не только мировоззрение, но и действие... Ей предстоит провести идею перемены во всех сферах жизни ... возбудить вкус к изучению вопросов, способствущих человеческому благу» [7, с. 158]. Під кінець своєї філософської діяльності В. Лесевич починає займати чіткі громадянські позиції і його «наукова філософія» набуває ознаків «практичної філоcoфiï».

В.Лесевич добре сприймав особисто подібні світоглядні трансформації, але в повній мірі через це пройшов М.Я. Грот. Він практично зміг знайти об'єднувальну основу для метафізики духовного і позитивнонаукового пізнання, побудувати відповідну філософську систему світоглядного пізнання духу. Філософська діяльність М. Грота розділялася немов би на два періоди, хоча він і знаходився у постійній творчій ево- 
люції. Перший період - позитивістський, переважно в концептуальних формах Г. Спенсера і А. Ланге. Другий період-метафізичний, в якому він намагається примирити позитивізм і трансценденталізм. Головні його праці- «Про психологію відчувань», «Філософія та тї загальні завдання», дисертаційні роботи «Психологія відчування»; «До реформи логіки», «Про душу в зв'язку з сучасними вченнями про силу». Він, як і багато інших філософів того часу, на підставі даних психологічної науки намагається відійти від метафізичного пояснення явищ нашого світу до позитивної науки. У своїх дослідженнях першого періоду М. Грот «очищає знання» від таких понять, як «душа», «свідомість», «свобода волі», вводячи для них універсальний термін «сенсоріум» $[3$, с. 10, 145]. Пізніше він розробляє концепцію «інстинкту розумності» і проводить її від людських відчуттів у космічні масштаби і тим самим далеко виходить за рамки позитивізму. «Інстинкт розумності» виводить, виштовхує людину за межі суб'єктивності у всесвіт і життя космосу. В такому статусі людина вже виступає носієм космічних вселенських начал, які не охоплюються логікою позитивізму і далеко виходять за його межі $[4$, с. 128$]$. У статті «Шо таке метафізика» М. Грот прямо пише, що «людина $є$ носієм вселенських начал», «одне із втілень нового розуму» $[4$, с. $17-18]$.

Подальший розвиток української філософської думки, вже на початку і у першій чверті XX століття представлений такими чотирма напрямками $[10$, с. 426-486]: соціально-філософське обгрунтування історіософії та розробка іï̈ національно-культурних засад в творчості М.Грушевського; розробка основоположень національної філософiї права Б. Кістяковським; створення філософсько-фізичного вчення про біосферу і ноосферу («живу речовину») В. Вернадським; розвиток філософської і соціополітичної думки західної української діаспори: В. Зеньковский, Г. Флоровський, Л.Шестов, Д. Чижевський, В. Петров, О. Кульчицький, Б. Цимбалістий. Особливий вплив на процеси політичного становлення і державотворення в Україні мали філософські і соціально-політичні погляди В. Винниченка («конкордизм»), Д. Донцова («інтегральний націоналізм»), В. Липинського («консервативна філософія історії»).

За В.В. Зеньковським - це безперервний процес «вільної форми духовної творчості», в ній присутня первісна широта духовної культури слов'янських народів з їх прадавнім корінням і потягом до «споконвічної інтуїції» в філософських і екзистенційних поглядах [5, с. 11-12]. $\mathrm{I}$ «понадчуттєвий досвід», і натхнення «вільного дослідження», і позачуттєва інтуїція в національній філософії відіграють особливу роль. 
Це висхідні методологічні засади національної філософської культури, яка знаходиться в безперервному пошуку синтезу істини і справедливості в «космічній правді». Але з іншого боку, розвивається світоглядний погляд про цілісність і раціональність «буттєвої реальності людини», яка $€$ «універсальною реальністю» об'єктивного і суб'єктивного, трансцедентально-метафізичного і позитивно-наукового, духовнореального і духовно-емпіричного. В цьому і полягає «духовна раціональність» філософії: «філософія є там, де $є$ шукання духовного життя на шляхах його раціоналізації $[5$, с. 14$]$.

На подібних підставах відомий український філософ В. Горський виділяє кілька періодів трансформації національного суспільного світогляду: від романтично-просвітницького і філософсько-культурного до національно-історичного і відроджувального [2, с.126-399]. За нашою концепцією, українське суспільство зараз вступає в новий період національно-світоглядних трансформацій, пов'язаний з формуванням громадянського суспільства.

\section{1 Бібліографія}

[1] Бичко A.K. Українські гуманісти епохи Відродження (у 2-х ч.). К.: Либідь, 1995.

[2] Горсъкий В.С. Історія української філософії. - К.: Наукова думка, 2001.

[3] Грот Н.Я. Философия и ее общие задачи.-Петербург: Изд. Моск. Псих. Общества, 1907.

[4] Грот Н.Я. Сборник статей о Н.Я. Гроте. - Петербург, 1911.

[5] Зенъковсъкий В.В. История русской философии. - Т. 1. - Ч. 1. Ленинград: Эго, 1991.

[6] Когут 3. Коріння ідентичності. Студії з ранньомодерної та модерної історії України. - К., Критика, 2004.

[7] Лесевич В.В. Письма о научной философии. - K., 1877.

[8] Лесевич В.В. Опыт критического исследования основоначал позитивной философии. - K., 1877.

[9] Литвинов В. Ренесансний гуманізм в Україні.- К.: Основи, 2000. 
[10] Огородник I.B., Огородник В.В. Історія філософської думки в Україні. - К.: Вища школа, 1999.

[11] Сковорода Г. Твори (у 2-х т.). - Т. 1. - K, 1961.

[12] Челпанов Г.И. Проблемы восприятия пространства. - T.II. - K., 1995.

[13] ШІnет Г.Г. Введение в этническую психологию // Сочинения. М.: Правда, 1989.

[14] Юркевич П. Сердце и его значение в духовной жтзни человека // Философские произведения. - М., Правда, 1990.

[15] Юркевич П. Из науки о человеческом духе // Философские произведения. - М., Правда, 1990.

[16] Яковенко Н. Паралельний світ. Дослідження з історії уявлень та ідей в Україні. - К.: Критика, 2002.

[17] Chinczewska-Gennel T. The National Consiousness of Ukraine // Ukrainian Studies. - 1996. - Vol.X. - №3/4. 